\title{
Purification and partial characterization of white radish (Raphanus sativus L. var. Long white) peroxidase from cell suspension culture extract
}

\author{
Sri Pudjiraharti and Andi Tenri Adjeng Karossi \\ Research Center for Chemistry, Indonesian Institute of Sciences, Jl. Sangkuriang, \\ Bandung 40135, Indonesia
}

\begin{abstract}
Peroxidase mainly Horseradish peroxidase (HRP) has been widely used as a component of clinical diagnostic reagent for Enzyme Linked Immunosorbent Assay (ELISA) technique. White radish (Raphanus sativus L.) was found as another source of peroxidase. In this study, white radish was used for the production of peroxidase by cell suspension culture technique. Isolation of the enzyme was conducted by ammonium sulfate precipitation followed by purification using DEAE-Cellulose column chromatography eluted with $0.01 \mathrm{M}$ phosphate buffer, $\mathrm{pH} 7.5$ and $0-0.5 \mathrm{M} \mathrm{NaCl}$ gradient. A major peak of protein having the highest activity and purity 25 folds compared to the crude enzyme was observed. This protein was partially characterized. SDS-Polyacrilamide gel electrophoresis showed one main band with molecular weight of $47.000 \mathrm{Da}$. This white radish peroxidase (WRP) is a very efficient enzyme with demonstrated maximum activity at temperature $55^{\circ} \mathrm{C}$ and $\mathrm{pH} 7.5$ as well as a $\mathrm{K}_{\mathrm{m}} 76.6 \mu \mathrm{g} / \mathrm{mL}$ and $\mathrm{V}_{\text {max }} 275 \mu \mathrm{g} / \mathrm{mL} /$ minute toward hydrogen peroxide as substrate and pyrogallol as hydrogen donor.
\end{abstract}

Key words: Peroxidase, white radish, cell suspension culture, purification, characterization

Correspondence: S. Pudjiraharti. Address: Research Center for Chemistry, Indonesian Institute of Sciences, Jl. Sangkuriang, Bandung 40135, Indonesia E-mail: sri.pudjiraharti@lipi.go.id DOI: 10.32945/atr3211.2010 


\section{INTRODUCTION}

Peroxidase is an oxidoreductase that catalyzes oxidation of several organic substrates of aromatic compounds such as fenol, hydroquinone, amine hydroquinone and benzidine derivatives by reducing hydrogen peroxide. Horseradish peroxidase has been widely used as a component of EnzymeLinked Immunosorbent Assay (ELISA) reagent for the detection of several hepatitis diseases $\mathrm{B}, \mathrm{C}$ and $\mathrm{G}$ as well as HIV diagnose .

Peroxidase has also been suggested to be used for several purposes such as treatment of waste water containing fenolic compounds, synthesis of aromatic compounds, elimination of peroxides from foods and industrial waste, biotransformation of isosafrole into piperonal as well as chalcone into biflavanones compound.

Commercial production of peroxidase was carried out by extracting the root of horseradish plant (Armorachia lapathifolia) that only grows in countries having relatively cool climate as agriculture gulma. To determine other sources of peroxidase having similar characteristic to HRP, screening on peroxidase activity of several local vegetables under the same family with horseradish (Brassicaceae family) was carried out. White radish was found to have the highest enzyme activity among the tested Brassicaceae family members.

Studies on the production of HRP by cell culture technique had been conducted by some researchers. Activity of the enzyme produced was much higher than the activity of enzyme isolated from horseradish plant. Therefore, it had also been reported the possibility of producing HRP by cell culture technique. However, only little amount of peroxidase production by cell suspension culture of white radish was reported.

In our previous study, we have shown the effect of naphtalene acetic acid (NAA) and kinetin on the production of WRP through cell suspension culture technique. WRP was found as intracelluler enzyme (in the callus) and extracellular (secreted into the medium) with the enzyme activity higher than that of white radish tuber.In this study, WRP from cell suspension culture supernatant was purified and the enzyme was characterized. 


\section{MATERIALS AND METHODS}

\section{White radish seed}

White radish seed of white, long and cylindrical shape variety was a product of China which was purchased from a local market in Bandung.

\section{Sterilisation of seed}

White radish seed was soaked in subsequently $70 \%(\mathrm{v} / \mathrm{v})$ ethanol for three minutes and $20 \%(\mathrm{w} / \mathrm{v})$ sodium hyphochlorite in $0.1 \%(\mathrm{v} / \mathrm{v})$ tween- 80 for 15 minutes. The seed was then washed five times with sterilized water for 15 minutes each to remove the excess of hyphochlorite.

\section{Seed germination}

Germination of seed was conducted on a medium of wet sterilized filter paper placed in a petridish incubated in the dark in a germination cabinet at $25 \mathrm{oC}$ for four days.

\section{Callus induction}

The cotyledon of white radish sprout was grown on Murashige-Skoog (MS) agar medium containing 5.73.10-7 M NAA and 4.64.10-6 M kinetin, and incubated in the dark in a germination cabinet at $25^{\circ} \mathrm{C}$ for three weeks (10). The callus was then subcultured on the same medium incubated at the same condition.

\section{Preparation of WRP by cell suspesion culture}

The friable calluses were transferred into $25 \mathrm{~mL}$ MS liquid medium containing various concentrations of NAA and kinetin(10). Incubation was done in a shaking incubator at dark condition with agitation speed of $120 \mathrm{rpm}$ for four weeks. Subculture was carried out every week by replacing one fourth portion of the old medium with three fourth portion of the same fresh medium. Peroxidase crude extract was obtained by filtering the culture to 
separate the biomass using filter paper. The filtrate was used as enzyme crude extract.

\section{Precipitation of WRP by ammonium sulfate fractionation}

Enzyme crude extract was saturated with ammonium sulfate with gentle stirring and the mixture was left overnight at $4^{\circ} \mathrm{C}$ after the salt was completely dissolved. To separate the supernatant from the precipitate, the mixture was centrifugated at $12.500 \mathrm{rpm}, 4^{\circ} \mathrm{C}$ for 20 minutes. The supernatant was then treated for further fractionation, while the precipitate was diluted with $0.01 \mathrm{M}$ phosphate buffer $\mathrm{pH} 6.0$ to determine the enzyme activity and protein concentration. The precipitate from ammonium sulphate fractionation with 30$80 \%$ saturation was diluted with $0.01 \mathrm{M}$ phosphate buffer $\mathrm{pH} 6.0$ and dialysed in cellofan tube with gentle stirring against $0.01 \mathrm{M}$ phosphate buffer $\mathrm{pH} 6.0$ at $4^{\circ} \mathrm{C}$ until all salts were removed from the solution.

Purification of WRP by anion-exchange column chromatography

The dialysed enzyme was then loaded on DEAE-Cellulose $(1 \mathrm{~cm} \times 25 \mathrm{~cm})$ column equilibrated with $0.01 \mathrm{M}$ phosphate buffer $\mathrm{pH}$ 7.5. The column was eluted with the same buffer and continued with a $\mathrm{NaCl}$ gradient from $0-0.5 \mathrm{M}$ at a flow rate of $1 \mathrm{~mL} /$ minute, collecting fractions of $5.0 \mathrm{ml}$ at $4^{\circ} \mathrm{C}$. The active fraction was then used for characterization.

\section{Analysis of enzyme activity}

Peroxidase activity was determined by spectrophotometric method using pyrogallol as hydrogen donor (14). Pyrogallol was converted by peroxidase in the presence of $\mathrm{H}_{2} \mathrm{O}_{2}$ at $20^{\circ} \mathrm{C}$ and $\mathrm{pH} 6.0$ to purpurogallin. The orange color of purpurogallin was measured at $300 \mathrm{~nm}$. Concentration of purpurogallin was calculated from calibration curve of purpurogallin standard. One unit of enzyme activity was defined as $\mathrm{mg}$ purpurogallin formed from pyrogallol at $20^{\circ} \mathrm{C}, \mathrm{pH} 6.0$ in five minutes. Protein enzyme concentration was analyzed by spectrophotometric method using Lowry reagent, and the blue-purple color 
resulted in the reaction was measured at $500 \mathrm{~nm}$. Concentration of the protein enzyme was calculated from the calibration curve of Bovine Serum Albumin standard which was determined using the same method.

\section{Characterization of enzyme}

Optimum temperature and $\mathrm{pH}$ of enzyme activity

To determine the optimal temperature of enzyme activity, the active fraction was assayed for its peroxidase activity at various temperatures $\left(30^{\circ}\right.$, $35^{\circ}, 40^{\circ}, 45^{\circ}, 55^{\circ}$, and $60^{\circ} \mathrm{C}$ ) in $0.01 \mathrm{M}$ phosphate buffer $\mathrm{pH}$ 7.5. For optimal $\mathrm{pH}$, enzyme activity of the active fraction was determined at optimum temperature in $0.01 \mathrm{M}$ phosphate buffer with various $\mathrm{pH}$ ranging from 5.0 to 8.0 .

\section{Measurement of molecular weight}

Analytical SDS-PAGE was performed generally according to the method of Laemmli (16). The sample, $50 \mu 1$, which had been treated with $1 \%$ SDS + $1 \%$ 2-mercaptoethanol at $80-90^{\circ} \mathrm{C}$ was loaded into the gels (upper gel: $4 \%$ polyacrylamide and lower gel: $15 \%$ polyacrylamide). Protein standards, with low molecular weights in the range of 14,000 to 94,000 were used to calibrate the gels. They were run at $20 \mathrm{~mA}$ and $30 \mathrm{~mA}$ for the upper and the lower gels respectively. After electrophoresis, the proteins were stained with Comassie Blue.

Estimation of Michaelis-Menten Constant $\left(K_{m}\right)$

$\mathrm{K}_{\mathrm{m}}$ value of the enzyme was determined by measuring the peroxidase activity of the active fraction at optimal temperature and $\mathrm{pH}$ using various concentrations of hydrogen peroxide as substrate $(\mathrm{b} / \mathrm{v})$ namely $0.004 \%$; $0.006 \% ; 0.008 \% ; 0.01 \% ; 0.012 \% ; 0.014 \%$ and $0.016 \%$. 
Table 1. Precipitation of WRP by eight steps ammonium sulfate fractionation.

\begin{tabular}{ll}
\hline (NH4)2SO4 Fraction & Precipitation \\
\hline $0-10 \%$ & No precipitate \\
$10-20 \%$ & No precipitate \\
$20-30 \%$ & Precipitate \\
$30-40 \%$ & Precipitate \\
$40-50 \%$ & Precipitate \\
$50-60 \%$ & Precipitate \\
$60-70 \%$ & Precipitate \\
$70-80 \%$ & Precipitate \\
\hline
\end{tabular}

\section{RESULTS AND DISCUSSION}

\section{Precipitation of WRP by ammonium sulfate fractionation}

WRP crude extract used for purification was obtained from the earlier experiment (10). Various concentrations of growth hormones such as NAA and kinetin were applied to MS medium for white radish cell suspension culture in order to find out the optimal composition for maximum enzyme activity. The culture of each composition was separated from the biomass using filter paper. The filtrate of all cultures were collected and used as crude enzyme. To determine the optimum concentration of ammonium sulfate giving the highest enzyme purity and yield, a portion of crude extract was fractionated using increasing levels of ammonium sulfate saturation with $10 \%$ interval. The result is presented in Table 1.

Since there was no precipitation observed at $0-20 \%$ saturation, six steps of fractionation were then applied starting from 0-30\% ammonium sulfate saturation. Low enzyme purity and yield was observed at the first and second step of fractionation (Table 2), Increasing level of saturation from $0-30 \%$ to $30-80 \%$ and $0-40 \%$ to $40-80 \%$ were further carried out and the results are shown in Table 3. At 0-30\% followed by 30-80 \% fractionation the highest enzyme purity and yield of 22.93 and $49.93 \%$ were attained respectively. To obtain sufficient amount of enzyme for the purpose of purification and characterization, $100 \mathrm{ml}$ of crude extract was fractionated by two steps of fractionation, $0-30 \%$ and $30-80 \%$, and dialyzed thereafter. As shown in Table 
Purification and partial characterization of Raphanus sativus L. var. Long white peroxidase
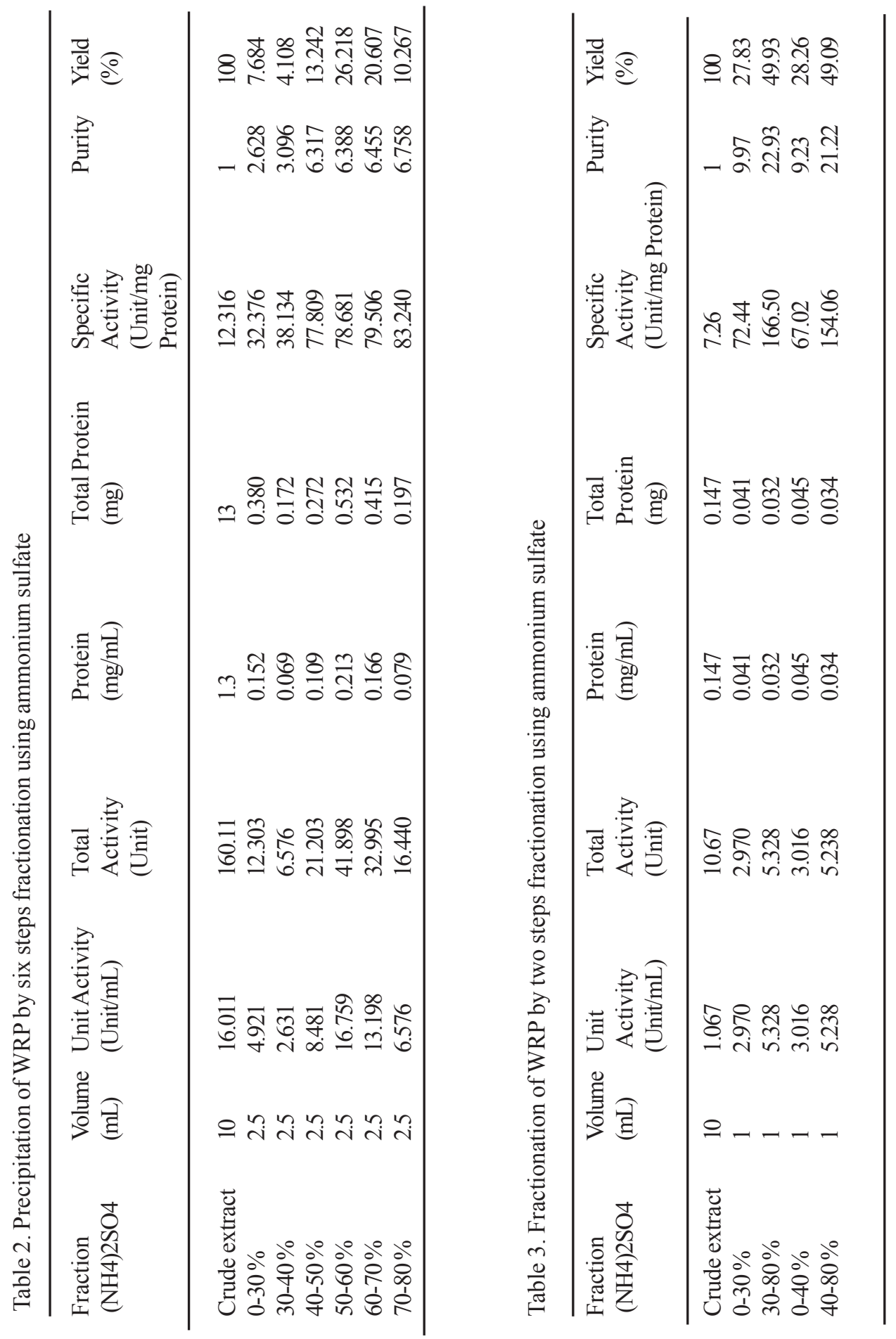
4, enzyme purity was increased by 17 folds compared to the crude extract. According to Wilkinson, et.al the good yield for enzyme purification is higher than $50 \%$. The low yield obtained in this study might be due to the low enzyme concentration in the crude extract enzyme, so that precipitation by ammonium salt became less effective. When collecting the enzyme crude extract, all of the medium broth of white radish cell suspension cultures having either high or low peroxidase activity were collected together in order to obtain an appropriate volume of enzyme for optimization of the fractionation process. After dialysis, the protein content of the crude extract decreased from 0.147 to $0.04 \mathrm{mg} / \mathrm{mL}$.

\section{Purification of WRP by anion-exchange column chromatography}

The dialysed enzyme was then subjected to DEAE-Cellulose column chromatography equilibrated with $0.01 \mathrm{M}$ phosphate buffer $\mathrm{pH} 7.5$ and eluted with the same buffer followed by $0-0.5 \mathrm{M} \mathrm{NaCl}$ gradient in the same buffer. Sixty seven fractions containing five $\mathrm{mL}$ eluate were collected and tested for peroxidase activity as well as protein absorbance at $280 \mathrm{~nm}$. At this wavelength, amino acids with aromatic ring (fenil alanine, serine, tyrosine and tryptophan) that are present in enzyme were absorbed at its maximum. The pattern of protein absorbance and enzyme activity of all fractions are summarized in Figure 1. It can be shown that one major protein peak with the highest peroxidase activity was observed at fraction number 9 . Based on its ionic properties, DEAE-Cellulose which has cationic functional group, diethylaminoethyl, would act as anion exchanger bounds anionic materials from the samples. This result suggests that the peroxidase is a cationic enzyme that was bounded weakly by the cationic matrix DEAE-Cellulose and detached at the beginning of elution. Purification with column chromatography increased enzyme purity 25 times higher than that of the crude enzyme (Table 4). Crude enzyme with relatively high protein concentration should be used in order to obtain higher yield. Membrane filtration to concentrate the enzyme might also be applied. 


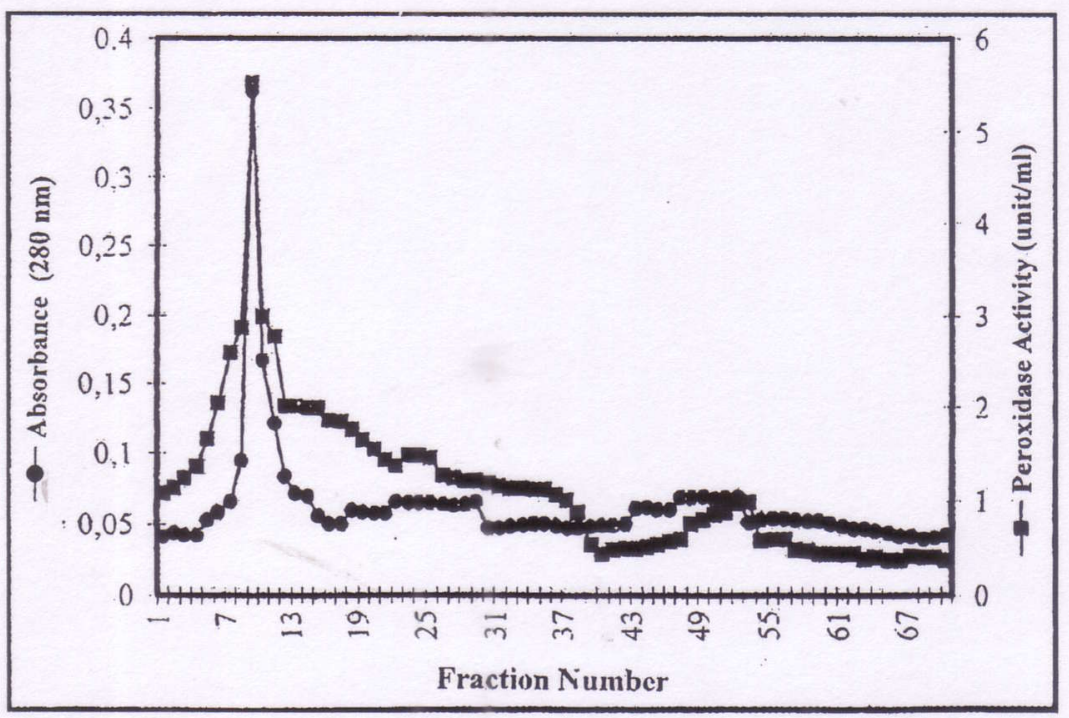

Figure 1.WRP elution profile on DEAE-Cellulose Anion Exchange Column Chromatography using $0.05 \mathrm{M}$ phosphate buffer $\mathrm{pH} 7.5,0-1.5 \mathrm{M} \mathrm{NaCl}$ linear gradient in the same buffer. Fractions were assayed for protein absorbance $(280 \mathrm{~nm})$ and peroxidase activity. 


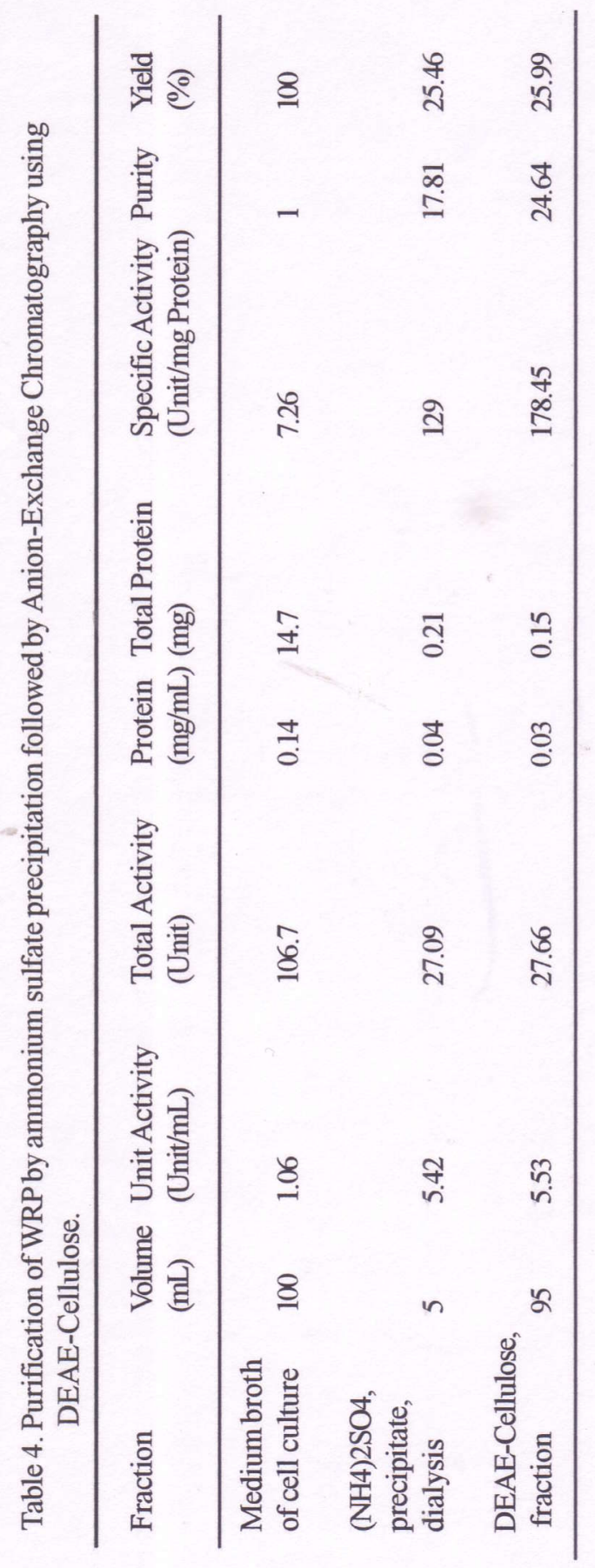




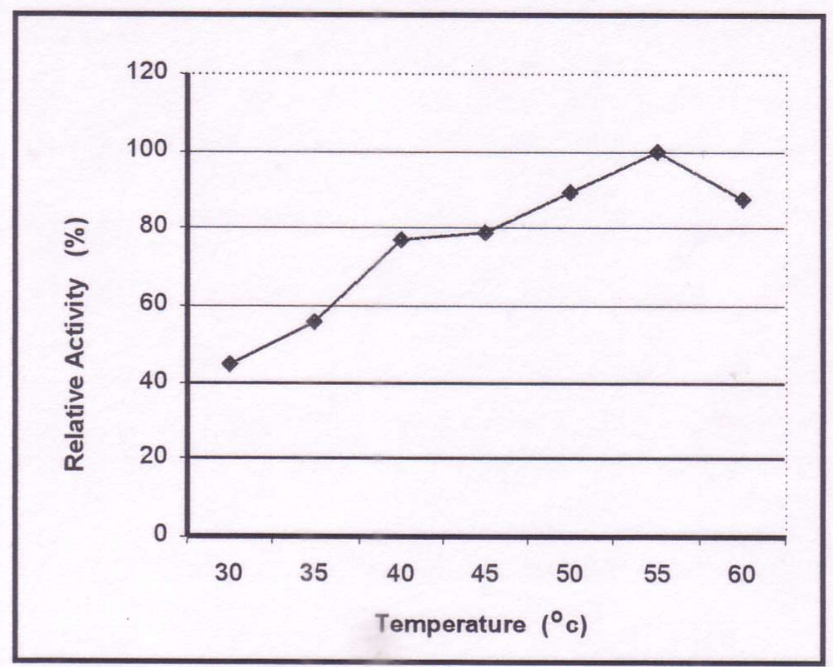

Figure 2. Relative activity of WRP peroxidase determined in phosphate buffer $\mathrm{pH} 7.5$ at various temperatures toward $\mathrm{H}_{2} \mathrm{O}_{2}$ as substrate for 5 minutes

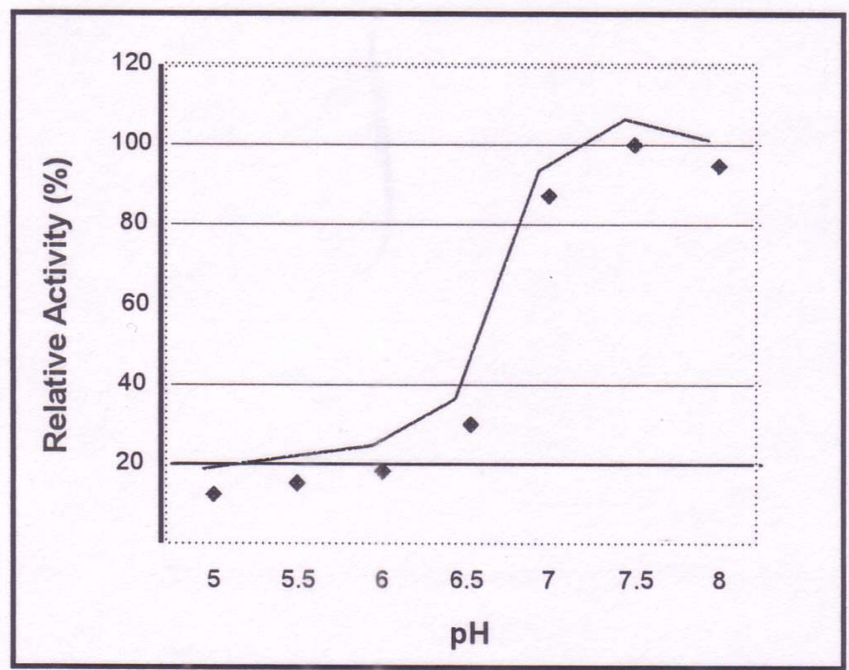

Figure 3. Relative activity of WRP determined at optimal temperature in phosphate buffer with various $\mathrm{pH}$ toward $\mathrm{H}_{2} \mathrm{O}_{2}$ as substrate for 5 minutes. 
Properties of WRP

\section{Optimum temperature and $\mathrm{pH}$}

The optimum temperature and $\mathrm{pH}$ for the activity of WRP is presented in Figures 2 and 3. Maximum enzyme activity was observed at temperature of $55^{\circ} \mathrm{C}$ and $\mathrm{pH} 7.5$. These results suggest that WRP is a thermophylic and neutral enzyme.

\section{Molecular weight of WRP}

SDS-PAGE of fraction 9 showed one major band (Figure 4.), indicating that WRP has only one subunit. Molecular weight of the sub unit was calculated by comparing the mobility of fraction 9 against protein standards using regression linear equation derived from Figure 5. WRP has molecular weight of 47.100 Da which is almost similar to the molecular weight of HRP isoenzyme (HRPi) 1 standard which is $47.900 \mathrm{Da}$ from SIGMA.

\section{Michaelis-Menten Constant $\left(K_{m}\right)$}

Michaelis-Menten Constant $\left(\mathrm{K}_{\mathrm{m}}\right)$ was estimated from double-reciprocal plots of the reaction rates against hydrogen peroxide concentrations using Lineweaver-Burk equation resulting to $-1 / \mathrm{K}_{\mathrm{m}}$ value of -13.05 , giving $\mathrm{K}_{\mathrm{m}}$ value of WRP of $76.6 \mu \mathrm{g} / \mathrm{mL}$ (Figure 6.). $\mathrm{K}_{\mathrm{m}}$ value describes the binding affinity of enzyme toward a substrate, Low $\mathrm{K}_{\mathrm{m}}$ values indicate higher enzyme reactvity to the substrate and favor more substrate-enzyme complex formation which in turn, produce more products. The low $\mathrm{K}_{\mathrm{m}}$ value of WRP obtained in this study, indicates that $\mathrm{WRP}$ is a very reactive enzyme against hydrogen peroxide. It can also be derived from Figure 6, the $V_{\text {max }}$ value was $1.3798 \mathrm{mg} / \mathrm{mL} / 5$ minutes. 


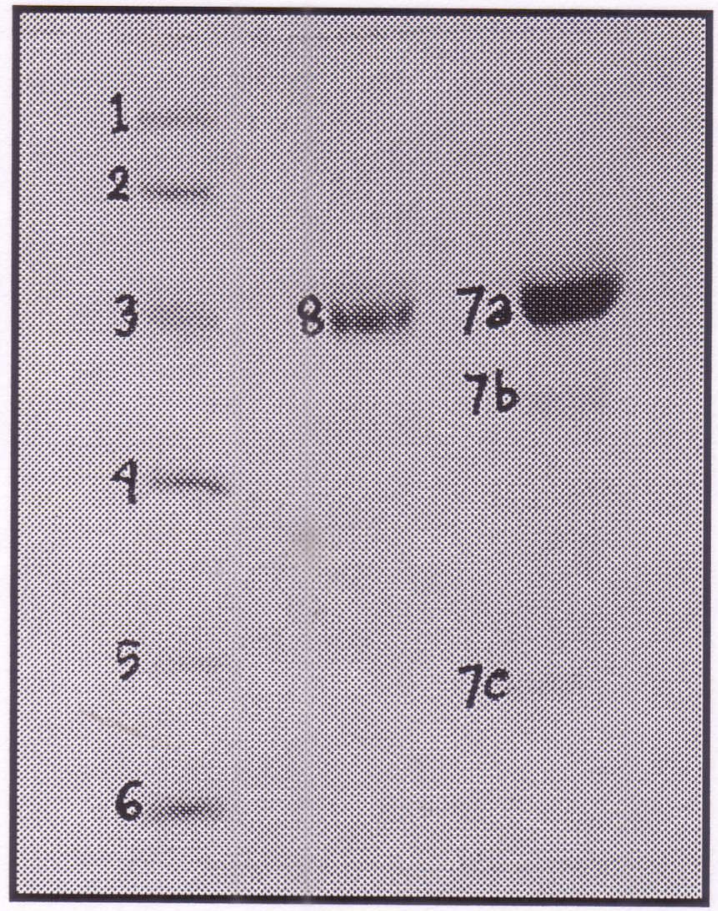

Figure 4. Subunit number of WRP by SDS-PAGE. Bands:(1) Fosforilase b, (2) Bovine Serum Albumin, (3) Ovalbumin, (4) Carbonate-Anhydrase, (5) Soybean Trypsine Inhibitor, (6) á-Lactalbumin, (7a) HRPi 1 (7b) HRPi 2, (7c) HRPi 3, and (8) Purified enzyme, fraction 9. 


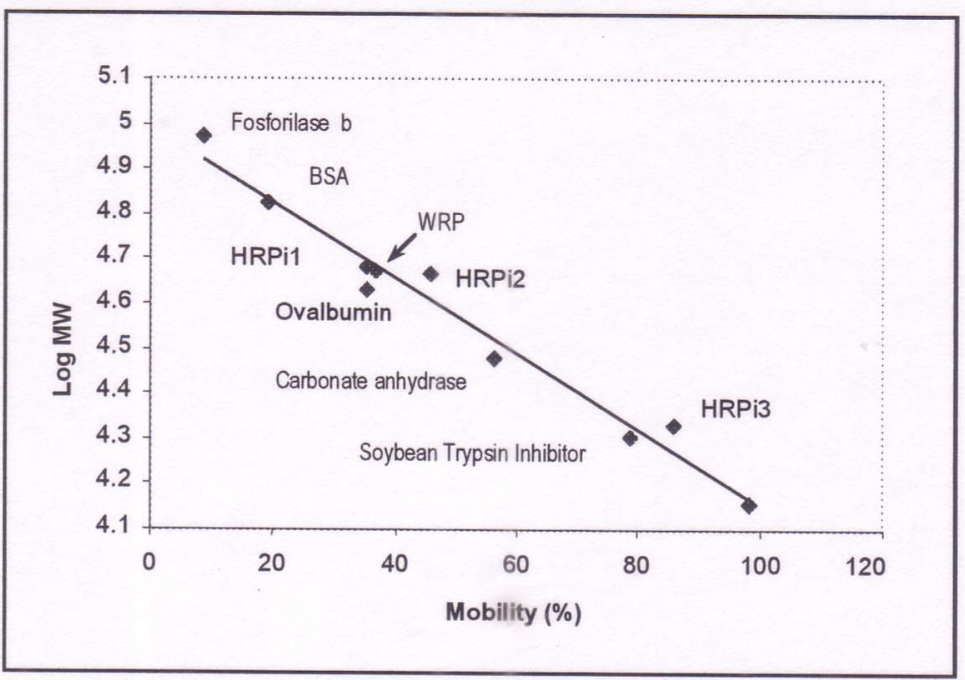

Figure 5. Molecular weight of WRP by SDS-PAGE. Log molecular weight is plotted as a function of mobility relative to the dye front. Protein standards: Fosforilase b, $94 \mathrm{kDa}$, Bovine Serum Albumin, $67 \mathrm{kDa}$, Ovalbumin, $43 \mathrm{kDa}$, CarbonateAnhydrase, $30 \mathrm{kDa}$, Soybean Trypsine Inhibitor, $20.1 \mathrm{kDa}$, á Lactalbumin, $14.4 \mathrm{kDa}$, HRPil, $47.9 \mathrm{kDa}, \mathrm{HRPi} 2,46.3 \mathrm{kDa}, \mathrm{HRPi} 3,21.4 \mathrm{kDa}$ and WRP 47.1 $\mathrm{kDa}$.

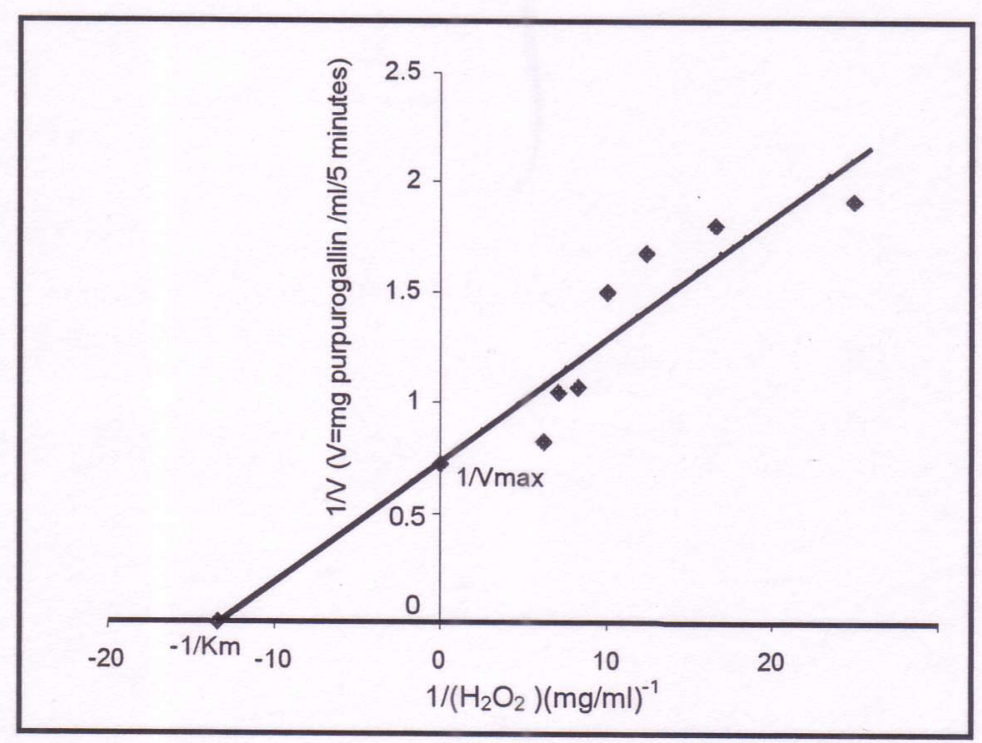

Figure 6. Lineweaver-Burk curve between reaction velocity of WRP against hydrogen peroxide concentration. 


\section{CONCLUSION}

Peroxides was produced from white radish (Raphanus sativus $\mathrm{L}$ ) through cell suspension culture technique. Ammonium sulfate precipitation using 0$30 \%$ saturation followed by $30-80 \%$ produced enzyme with high degree of purity and yield. This was followed by DEAE-Cellulose column chromatography eluted with 0.01 phosphate buffer, $\mathrm{pH} 7.5$ and $0-0.5 \mathrm{M}$ $\mathrm{NaCl}$ gradient which purified the enzyme 25 folds compared to the crude enzyme. The molecular weight of WRP was $47.000 \mathrm{Da}$, with maximum activity at temperature $55^{\circ} \mathrm{C}$ and $\mathrm{pH} 7.5$. It has a $\mathrm{K}_{\mathrm{m}}$ value of $76.6 \mu \mathrm{g} / \mathrm{mL}$ and $\mathrm{V}_{\max }$ of $275 \mu \mathrm{g} / \mathrm{mL} /$ minute toward hydrogen peroxide and pyrogallol.

\section{ACKNOWLEDGMENTS}

This experiment was supported by the Government of Indonesia through DIPA Project of Indonesian Institute of Sciences (LIPI). The authors wish to thank Prof. A. Sidik for his very worthy ideas, Dr. Julie Diamante for the language corrections and R. Berliani, who had assisted this work.

\section{REFERENCES}

ANDRADE, J.L., M. S. LEMOS, A. S. SANTOS, O. A C. ANTUNES and N. PEREIRA, JR. Peroxidase production and application in the isosafrole biotransformation into piperonal. www.eere.energy. gov./biomass/biotech_symposium/docs/1b62.doc.

ANONYMOUS. 1991. Ion exchange chromatography. Principles and Methods. Sweden: Pharmacia Fine Chemicals.

CHEN, HUEY-LING, CHANG MEI-HWEI, NI, YEN-HSUAN, HSU, HONG-YUAN, KAO, ЛА-HORNG, and CHEN, PEI-JER 1997. Hepatitis G virus infection in normal and prospectively followed posttransfusion children. Pediatric Research 42(6): 784787.

COLOWICK, SP. and N. O. KAPLAN. 1957. Methods in Enzymology, Vol III, Acad. Press. Inc., New York.

FIELDING J. L. and A. HALL. 1978. Biochemical and cytochemical study of peroxidase activity in root of Pisum sativum. J. Exp. Bot. 29:969-981. 
ISKANDAR, Y.M., S. PUDJIRAHARTI and A. T. KAROSSI. 1996. Production of peroxidase from Armorachia lapathifolia (Horseradish) callus. In: Proceeding of Pemaparan Hasil Litbang Ilmu Pengetahuan Teknik. Bandung, 14-26 October, 1996.

JOON-SUPYEOM, JAE-BEOMLEE, SEUNG-HO RYU, HEE-JUNG KANG SUNHIL KIM, YOUNG-A KIM, SUN-YOUNG AHN, JE-EUN CHA and JAE-WON PARK. 2006. Evaluation of a new third-generation ELISA for the detection of HIV infection. Annals of Clinical \& Laboratory Science 36:73-78.

KOTWAL, G.J., B. M. BAROUDY, I. K. KURAMOTOT, F. F. MCDONALD, G M. SCHIFF, P. V. HOLLANDT and J. B. ZELDIS. 1992. Detection of acute hepatitis C virus infection by ELISA using a synthetic peptide comprising a structural epitope (early diagnosis/blood screening). Proc. Nati. Acad. Sci. 89: 4486-4489.

LAEMLI, U.K. 1970. Cleavage of structural proteins during the assembly of head of bacteriophage T4. Nature 227: 680-685.

LEE, T. T. 1973. Extraction and quantitation of plant peroxidase isoenzyme. Plant. Physiol. 29:198-203

MURASHIGE, K.1974. Plant Propagation through tissue culture. Ann Rev. Plant.Physiol. 25: 35-36.

PUDJIRAHARTIS., T. A. BUDIWATI and A. T. KAROSSI. Peroxidaseproduction through cell suspension culture technique of Raphanus sativus L.var.long white. In: Proceedings of Indonesian Chemistry Society Seminar. Jakarta 22 February, 2006

SAUNDERS, B.C., A. G. HOLMES SIEDLE and B. P. STARK. 1974. Peroxidase. Butterworth Co. Ltd, London.

VITALI A, B. BOTTA, G. D. MONACHE, S. ZAPPITELLI, P. RICCIARDI, S. MELINO, R PETRUZELLI and B. GIARDINA.1998. Purification and partial characterization of a peroxidase from plant cell cultures of Cassia didymobotrya and biotransformation studies. Biochem J., 331: 513-519.

WILKINSON, M.L., J. M. GRIFFITHS and R. R. ALEXANDER. 1985. Basic Biochemical Methods. John Willey and Sons, New York.

YAMADA, Y., K. SETSUO, K. WATANAKA, and H. UZO. 1987. Production of Horse Radish Peroxidase by Plant Cell. J. Chem. Tech. Biotech. 38:31-39 